Esta publicación cientifica en formato digital es continuidad de la revista impresa ISSN-Versión Impresa 0798-1406 / ISSN-Versión on line 2542-3185Depósito legal pp
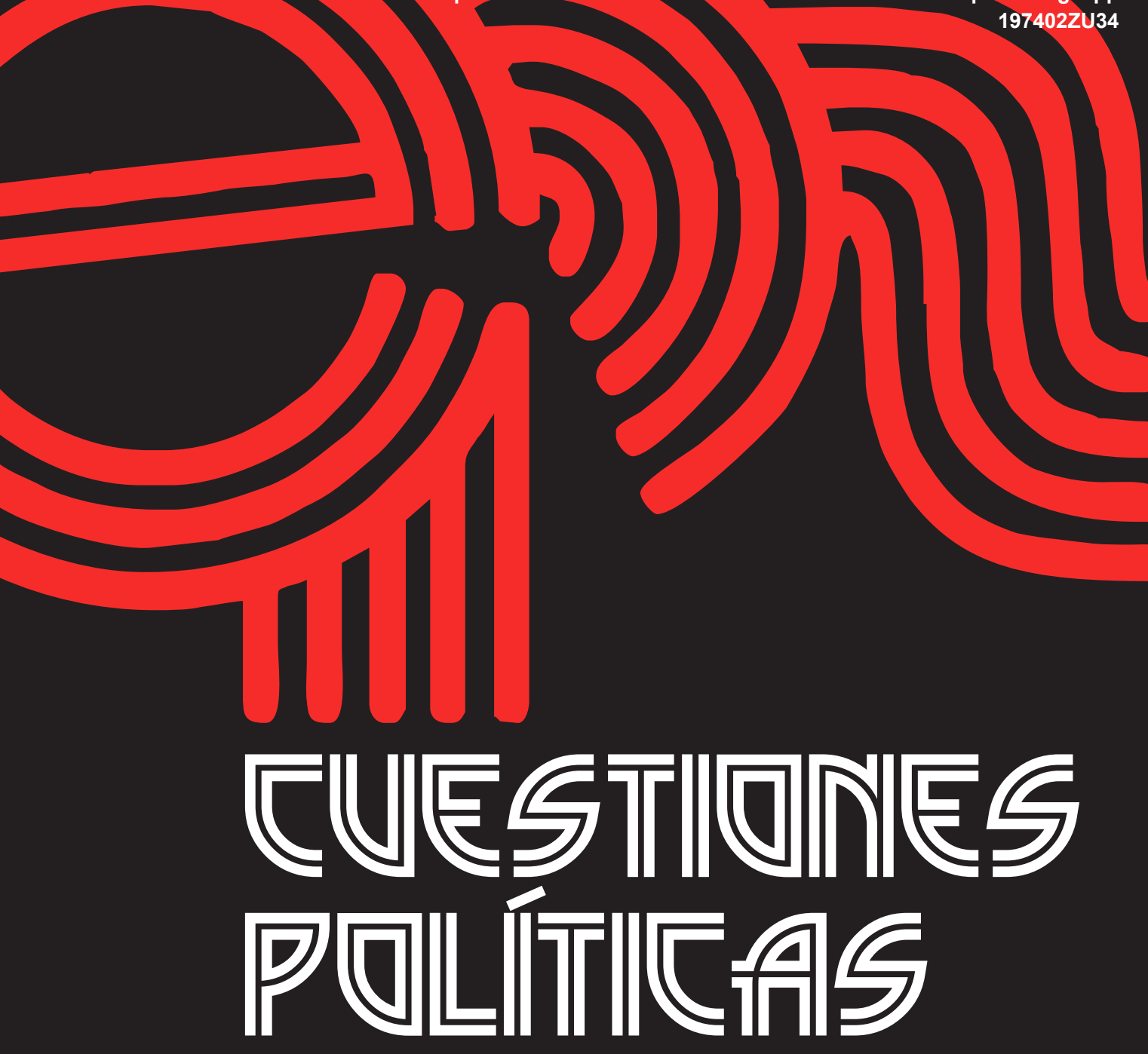

Instituto de Estudios Políticos y Derecho Público "Dr. Humberto J. La Roche" de la Facultad de Ciencias Jurídicas y Políticas de la Universidad del Zulia Maracaibo, Venezuela
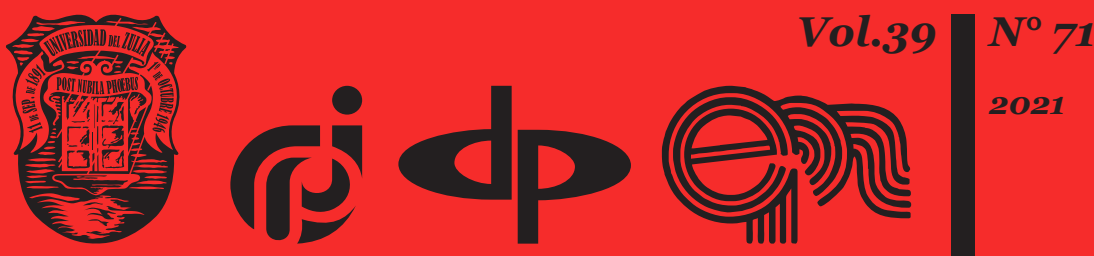


\title{
The concept and structure of activities in the field of organizing and holding elections to government bodies in the theory of constitutional law
}

\author{
DOI: https://doi.org/10.46398/cuestpol.3971.41 \\ Natalia Keshikova * \\ Igor Demeshko **
}

\begin{abstract}
The article aims to study the concept and structure of activities in the field of the organization and holding of elections to governing bodies in the theory of constitutional law. The main method was the analysis of systems that allows to study the system of activities in this field. The latter can be represented by different structures depending on the stage of their cognition as an object or their internal processes. In addition, the article used the historical method, deduction, induction, etc. It is concluded that the system of activities in the field of the organization and holding of elections to the governing bodies is a unit of their properties and integral elements, order and their interaction, as well as stable connections between them, based on the principles of preservation or invariance, which are organized as appropriate relations between the structural elements themselves and their external environment, that is, the sphere of the organization and conduct of elections to the governing bodies.
\end{abstract}

Keywords: political activity; area of the organization and conduct of elections; electoral process; elemental composition; functional-intentional method.

Irkutsk Institute (Branch) of the All-Russian State University of Justice, Irkutsk, Russia. ORCID ID: https://orcid.org/oooo-0002-9866-3464

** Department of Legal work of the Administration of the City of Irkutsk, Irkutsk, Russia. ORCID ID: https://orcid.org/oooo-0001-9095-4243

Recibido el 14/09/2021

Aceptado el 22/11/2021 


\section{El concepto y la estructura de las actividades en el campo de la organización y celebración de elecciones a órganos gubernamentales en la teoría del derecho constitucional}

\section{Resumen}

El artículo tiene como objetivo estudiar el concepto y la estructura de las actividades en el campo de la organización y celebración de elecciones a los órganos de gobierno en la teoría del derecho constitucional. El método principal fue el análisis de sistemas que permite estudiar el sistema de actividades en este campo. Este último puede ser representado por diferentes estructuras dependiendo de la etapa de su cognición como objeto o sus procesos internos. Además, el artículo utilizó el método histórico, la deducción, la inducción, etc. Se concluye que el sistema de actividades en el campo de la organización y celebración de elecciones a los órganos de gobierno es una unidad de sus propiedades y elementos integrales, el orden y su interacción, así como conexiones estables entre ellos, basadas en los principios de preservación o invariancia, que se organizan como relaciones apropiadas entre los propios elementos estructurales y su entorno externo, es decir, la esfera de la organización y celebración de elecciones a los órganos de gobierno.

Palabras clave: actividad política; esfera de la organización y celebración de elecciones; proceso electoral; composición elemental; método funcional-intencional.

\section{Introduction}

Constant transformation processes in a state-organized society stipulate the need to adapt activities in the field of organizing and holding elections to government bodies to changing conditions. One of the key directions of such adaptation is the transformation of the system-structural approach and the improvement of the functional-purposeful organization of such activities. Today, there is a large discrepancy (inconsistency) between the actual system and structure of activities in the field of organizing and holding elections to government bodies and those enshrined in the current legislation. This fact is reflected in the relevant judicial practice (Supreme Court of The Russian Federation, September 2, 2019; Supreme Court of The Russian Federation, September 7, 2019; Supreme Court of The Russian Federation, September 16, 2019).

The constitutional and legal regulation of this activity does not fully meet the requirements of the system-wide approach both at its system-structural 
level (the invariant of the system-structural organization of the activity under study) and at the functional-purposeful level. In particular, it is expressed in the fact that federal election law lacks the goals and objectives of both the legal regulation of organizing and holding elections to government bodies and the goals and objectives of its manifestations, namely, activities in the field of organizing and holding elections to government bodies. This state of affairs develops alongside an equally difficult situation in the science of constitutional law, where insufficient attention is paid to the very activity in the field of organizing and holding elections to government bodies in general and its system-structural and functional-purposeful organization in particular.

\section{Methods}

The scientific methodological study of the systemic and structural organization of the above-mentioned activity stipulates the need to determine positions on the relationship between the concepts of system and organization, system and structure, as well as clarify the understanding of the structure of activities in the field of organizing and holding elections to government bodies. According to the systemic approach, the concept of "structure of activities in the field of organizing and holding elections to government bodies" should be correlated with the concepts of "system" and "organization".

At the same time, it is difficult to classify such concepts as "system/ structure/organization of activities in the field of organizing and holding elections to government bodies" since there is no single viewpoint on the correlation of generic concepts "system", "structure" and "organization". We will share the initial prevailing opinion that the concept of "system" is the broadest one among the above-mentioned generic concepts. It gives an idea about various manifestations of a complex object of cognition. In this case, they are manifestations of activities in the field of organizing and holding elections to government bodies (its elements, structure, connections, functions, goals, etc.).

The concept of "structure" in relation to the "system" concept expresses only something that remains stable and relatively unchanged under various transformations of the system (Obshchii Tolkovyi Slovar Russkogo Yazyka, n.d.). Therefore, we will build our further research on the interpretation of the structure of activities in the field of organizing and holding elections to government bodies as one of the aspects (invariants) of their system.

Finally, the generic concept of "organization" embraces both structuralstatic and communicative-functional characteristics of a system that ensure its stability, balance and directed functioning. Organization is usually 
presented as internal orderliness and coherence of interacted elements of the structure, which manifests itself in the limited diversity of states common to the elements within its structure. As a rule, it is much easier to define the structure of a system as its internal organization. Consequently, the organization of activities in the field of organizing and holding elections to government bodies is an integral property of the system of this activity.

Furthermore, science has not found a universal answer to the question of what the system is. Its traditional semantic understanding includes several meanings, namely: 1 . the interposition and connection of the constituent parts, elements of something; structure; 2. arrangement, organization or structure, internal settlement (Obshchii Tolkovyi Slovar Russkogo Yazyka, n.d.).

In philosophy, the structure of a system is described in different ways. Within the framework of the communicative approach, it is defined as a set of stable connections of an object ensuring its integrity and identity, which presupposes the preservation of basic properties under various external and internal changes. The communicative approach can be supplemented with functional components when a structure is regarded as a set of not only organized connections but also the relations among its elements (Poleshchuk, 2015).

A different position is formed under the influence of the systemicstructural method of cognition, according to which a structure is formed as a relatively stable unity of elements, their relations and the object integrity expressed as an invariant aspect of this system. The system-purposeful approach can be traced in I. Kant's understanding of a structure, which is described as "the position and connection of parts of an organism formed for a specific purpose" (Kant, 1994: 217-218). As a result, we deal with different definitions of both structure and system.

To find a certain compromise, the structure of a system should be assessed based on several approaches. Logically, this position is consistent with our ideas about activities in general and activities in the field of organizing and holding elections to government bodies in particular, based on the use of various, multifaceted techniques, methods and means of cognizing objects of state and legal reality via methodological pluralism. In this regard, activities in the field of organizing and holding elections to government bodies are studied in the context of the integrated approach comprising positivist, systemic, axiological and anthropological methods of analysis. Accordingly, the structure of this activity is formed as a multifaceted phenomenon with various invariants of its existence and functioning. Therefore, a structure requires an integrated approach to its cognition and science makes such attempts. 
For example, a team of scholars (Sadovskii, Babaitsev, Drozdov, Chernyshov, Chernyshov, Aleksandrov) argue that the structure of a system presupposes orderliness, organization and arrangement conditioned by the relationship between the elements and its relationship with the external environment. This manifests two opposite properties of the system: limitation (an external property of the system) and integrity (an internal property of the system) (Sadovskii et al., 2021).

This definition is based on a set of techniques underlying the understanding of a structure: system-structural (organization, structure), communicative (relationships between elements), environmental (its relationship with the external environment). Another complex definition of the "structure" concept represents it as the composition, order and principles of interaction among system elements that determine the basic properties of this system (Information Systems And Networks, n.d.), relying on the system-structural, normative and communicative cognition.

In our case, the structure of activities in the field of organizing and holding elections to government bodies is a unity of its integral properties and elements, the order and principles of their interaction, as well as stable connections between them, which are organized by the corresponding relationship between the structural elements and its relationship with the external environment, i.e., the sphere of organizing and holding elections to government bodies.

We should pay attention to the fact that the same system of activities in the field of organizing and holding elections to government bodies can be represented by different structures, depending on the stage of its cognition as an object or its inner processes, the aspect of their consideration and/or the purpose of creation (Volkova and Denisov, 2014). Generally, the system of activities in the field of organizing and holding elections to government bodies can be represented by "a simple listing of elements (objects, subjects, principles, means, results)" (Vedeneev, 2003: 85; Biktagirov, 2010; Krasnov, 2000).

However, a comprehensive analysis presupposes "the representation of a system by dividing it into different and interconnected subsystems, components, elements, and their subsequent integration into a structure" (Volkova and Denisov, 2014: 40). In any case, the structure of activities in the field of organizing and holding elections to government bodies establishes the role and purpose of elements in the system of activities in this area, their location and relationship with each other.

Moreover, the system of activities in the field of organizing and holding elections to government bodies is closely related to its composition. This structure presupposes the decomposition of the system of a given activity, i.e., the division of a single (whole) system into its constituent elements. On 
the contrary, its structure provides the composition of the system of activity and the combination of its components (Yamashkin and Novokreshchenova, 2016). Thus, the structure of activities in the field of organizing and holding elections to government bodies characterizes the overall organization, the stable arrangement of its elements and connections between them.

Let us proceed from a general understanding of the structure of activities in the field of organizing and holding elections to government bodies to its composition. The science of constitutional law does not provide direct answers to this question. To fill the existing gaps in the science of constitutional law, we need to analyze scientific views related to the systemic-structural organization of a given activity, to determine their positive and negative aspects for this research. The generalization of some characteristics of the structure of the procedure for organizing and holding elections to government bodies (the election process) will allow to use them for the comprehension of the structure of the subject under study, i.e., the system of activities in the field of organizing and holding elections to government bodies as a manifestation of this order.

Currently, no scientific works study the structure and composition of the procedure for organizing and holding elections to government bodies. The latter is regarded as an activity carried out in the field of organizing and holding elections to government bodies. The election process is also an external expression of the procedure for organizing and holding elections to government bodies.

In this context, it is quite logical and expedient to study the structure of activities in the field of organizing and holding elections to government bodies from the particular (election process) to the general (the procedure for organizing and holding elections to government bodies as activity). To attain this end, we have analyzed several scientific works considering the structure of the election process. The above-mentioned ideas will be considered and serve as a starting point for the further development of our own viewpoint on the structure of activities in the field of organizing and holding elections to government bodies.

First of all, we need to refer to R.G. Mazitov's position. While considering the content and functioning of the election process in the context of the political process as a whole, the scholar argued that the election process was a form of implementing public power, its political reproduction and recognition. In his opinion, the election process was a dynamic phenomenon consisting of the purposeful activity of the subjects of the election process aimed at implementing the constitutional right of citizens to elect and be elected to representative bodies of power (Mazitov, 2009).

If the question is posed in such a way, R.G. Mazitov identified the form (process) and content (activity) of the procedure for organizing and 
holding elections to government bodies, which is incorrect from the general philosophical perspective. R.G. Mazitov formed the concept of "election process" by summarizing the main scientific positions on this issue and used several interdisciplinary research methods (political-legal, procedural, activity-based).

As a result, his concept of the election process tends rather to the category of the so-called integrative. The scholar's merit lies in the application of the integrated approach to studying the concept of "election process". Despite its eclecticism, his approach claims to be unique. R.G. Mazitov's opinion on the inner structure of the election process is also constructive for our research. Based on his provisions on the election process, we can determine the following elemental composition of such a process:

- Subjects of the election process (participants in a particular electoral campaign).

- The goal of the election process (the formation of elected bodies of state power and local self-government).

- Specific election actions and procedures associated with certain stages of preparation and conduct of elections.

U.S. Iskandarov emphasized that the current election law of Russia identified the election process with the procedure for organizing and holding elections as a form of exercising subjective voting rights reflecting the technology of voters' participation in the exercise of power. While developing his concept of the election process, U.S. Iskandarov (2007) distinguished between two external forms: the procedure for organizing and holding elections as a set of legal norms and the election process aimed at the election of officials, the implementation of the enshrined legal rights and obligations through a certain sequence of electoral actions.

The author also drew attention to the existence of procedural norms establishing the procedures for exercising electoral rights in the election process along with the substantive norms governing the procedure for organizing and holding elections. We agree with the scholar on this matter. However, he narrowed the procedure for organizing and holding elections and identified it with a set of legal norms. As a result, the procedure for organizing and holding elections loses its procedural aspect, which creates the actual form of the corresponding order.

According to V.V. Ignatenko, the election process is a legally regulated procedure for organizing and holding elections that ensures the legitimacy of voting and election results. Its structure consists of relatively independent stages that differ from each other in tasks, participants and their legal status, the types of electoral documents and the final results of procedural activities. 
This position is characterized by a different approach to the structure of the election process. In this context, the structure of the election process is presented at two levels. The top level consists of stages as constituent elements. At the lower level of the structure, each stage of the election process unites participants, tasks, electoral documents, and the final results of procedural activities as certain elements.

Thus, V.V. Ignatenko defined the election process as a system of a higher order, comprising systems of a lower order (subsystems) that play the role of stages of the election process. However, this system analysis of the election process is not completed, and the elemental composition of its subsystems (stages) is not fully determined. They lack such invariable elements of procedural activity as goals, principles, functions, objects, means and methods. In addition, we should not equate the procedure for organizing and holding elections with the election process. The latter is only part of the procedure for organizing and holding elections that forms one of its stages (sub-processes), i.e., the procedure for holding elections.

We should dwell on A.V. Ivanchenko's viewpoint, who considered the election process

a technological infrastructure and a form of realizing the constitutional functions of elections and the principles of organizing periodic free elections and ensuring the electoral rights of a person and a citizen within the sequence of performing complex electoral actions and procedures stipulated by law (Ivanchenko, 1999: 255-256).

Undoubtedly, this understanding of the election process was based on the technical and instrumental approach. As for the structure of the election process, A.V. Ivanchenko identified electoral actions and procedures, election functions and two types of principles (the first is the principles of organizing periodic free elections; the second is the principles of ensuring the electoral rights of a person and citizen). In addition, the concept of "technology" used by the author presupposes the inclusion of methods and techniques in the structure of the election process (Bychenkov, 2018). Despite positive aspects, A.V. Ivanchenko's approach has certain shortcomings. In particular, the scholar did not designate the subjective component as an independent element, as well as the conscious-volitional component (goals and tasks). As a result, the concept of the election process is reduced to a purely technical and instrumental configuration.

It is worth mentioning the position of A.V. Zinoviev and I.S. Polyashova on the concept and structure of the election process. They tried to summarize the existing definitions of the election process. The generalized version interprets the election process as a subinstitution of the electoral system and as a special type of activity characterized by a complex, polystructural and multifunctional nature since it covers the actions of all subjects (state 
bodies, election commissions, citizens, their political associations, etc.) (Zinovev and Polyashova, 2003: 156).

While emphasizing the polystructural and polyfunctional nature of such activities, A.V.Zinoviev and I.S. Polyashova did not determine substructures in the election process as independent elements of this activity and did not include functions in the structure of the election process as activity. Based on the proposed definition of the "election process", its structure comprises legal norms, actions and subjects.

According to S.D. Knyazev (1999b), it is preferable to define the election process not through the activities of competent entities but as a system of interrelated and implemented in a set of relations that mediate the preparation and conduct of elections. In his opinion, this understanding of the election process meets the interests of a comprehensive representation of this multifaceted political and legal phenomenon and clearly shows its relationship with electoral procedures and forms.

We must give credit to S.D. Knyazev who tried to fully reflect the internal structure of the election process and form certain types of components in its structure: subjective, technological, and institutional (stadial). The subjective component of the election process encompasses participants in some election campaign who, due to their endowment with procedural rights and obligations, act as subjects of the election process. The technological component includes temporary (terms) and formal (election documents) that make up the legal regime of election campaigns.

The institutional component comprises the stages of preparation and conduct of elections based on electoral actions and phases. According to the rules of system-structural analysis, the institutional component of any system is represented by its subject composition (actors) (Chernyshov and Chernyshov, 2008; Danelyan, 2010; Gerasimov, Popova, Zlobina, 2011).

In legal science, this path is followed primarily by theorists of state and law, revealing the legal system of society, where its institutional component is the composition of subjects and participants (the subjective component) (Melekhin, 2009). Consequently, the institutional level of the election process includes only its subjects. At the same time, the author's merit is an attempt to combine its elemental composition into groups based on certain criteria (actors, tools, stages) within the framework of the election process.

The rational kernel is contained in D.M. Khudolei's ideas on the essential features and stages of the election process (Khudolei, 2015). The scholar attempted to consider the election process from the viewpoint of its content: legal (electoral rights and obligations) and actual (the activities of various participants in the preparation and conduct of elections) within the process-functional approach. 
R.T. Biktagirov defined the election process as a complex and integrative (collective) category of the science of election law, election system and practice of election campaigns expressed in the legal relations that develop between elements of the election system during the preparation and conduct of general elections to state and local self-government bodies. The scholar emphasized that the election process was the purposeful activity of subjects of election law to implement the subjective constitutional right of citizens to elect and be elected to government bodies, on the one hand, and the power-related activity of voters in the formation of government and local self-government bodies, as well as on the empowerment of elected officials, on the other hand, performed through electoral actions and procedures in the manner and terms provided for by the procedural norms of election law (Biktagirov, 2012-2020).

Thus, R.T. Biktagirov declared two types of activities conducted by the subjects of election law: law-enforcement and power-related. As a result, the author highlighted the legal will of the subjects of election law, the goal to achieve a certain political and legal result, the political and legal result reproducing and legalizing public authority as elements of the election process. Within the framework of this article, it is crucial to consider the election process through the activity-based approach.

While defining the election process as a purposeful activity of subjects aimed at the implementation of their active electoral rights, the scholar dwelled on only one aspect, namely, the power-related activity of voters in the formation of government and local self-government bodies, as well as in empowering elected officials. He neglected the second aspect, i.e., the power-related activities of competent public authorities and the exercise of passive electoral rights by other subjects.

Finally, M.V. Maslovskaya (1999) examined the actions of subjects and participants in the election process in terms of their form and content. Functional content can be expressed in the activities of actors, and such actions are formalized in the form of temporary stages, from which the election process is formed.

This position correlates with our opinion on the correlation of the election process as a procedure for organizing and holding elections to government bodies with activities in the field of organizing and holding elections to government bodies considered as the content of this procedure. For some reason, M.V. Maslovskaya substituted these concepts and highlighted the elements of activity (subjects and participants, actions, material and legal results, election technologies) as essential characteristics of the election process.

A critical review of the above-mentioned constitutionalists allows us to draw a number of our own conclusions. As we can see from the corresponding 
analysis, the views of constitutional scholars on the understanding and the elemental composition of the election process are not the same, there is no universal and unified approach. On the one hand, some authors see the concept of "election process" in a broader sense, while the others interpret it in a narrow sense.

In the first case (broader understanding), scholars include elements of activities in the field of organizing and holding elections to government bodies into the structure of the election process. Thus, the system of a lower order (less structural) or the election process is endowed with the properties typical of a system of a higher order (more structural), including the properties and elements of activities in the field of organizing and holding elections to government bodies. We believe that the election process is only a part of the procedure for organizing and holding elections to government bodies as activity.

On the other hand, the other authors mix two concepts and use the concept of "election process", which has not been enshrined in law, as a legal category identified either with the procedure for organizing and holding elections or with activities in the field of organizing and conducting elections to government bodies, which, in our opinion, seems incorrect from the methodological viewpoint.

These concepts (the election process and activities in the field of organizing and holding elections to government bodies) have their own content and, accordingly, a different structure. Moreover, the election process is part of the procedure for organizing and holding elections, which forms a stage of this order, namely, the stage of holding elections.

The current elaboration of the above-mentioned issue is conditioned by the following reasons: firstly, an imbalance in the development of theories regardless of their scientific significance (for example, disputes about the relationship of the concepts of "election process", "procedure for organizing and holding elections", "election system", the study of the order of organizing and holding elections in a purely theoretical field (Demeshko, 2015, 2016); secondly, the lack of adequate consideration of the relationship among such categories as "election process", "procedure for organizing and holding elections" and "election system" (Keshikova, 2001; Keshikova and Demeshko, 2015).

In addition, the current situation was influenced by the absence of a clear understanding of activities in the field of organizing and holding elections to government bodies, its main parameters (features) and elemental composition in the science of constitutional law. This subsequently leads scholars to an unjustified identification of activities in the field of organizing and holding elections to government bodies with the election process, election campaigns, etc. and the most diverse assessments of the elements that form the structure of such an activity. 


\section{Results}

To fix the existing situation, we need to form our own opinion on the structure of activities in the field of organizing and holding elections to government bodies. For these purposes, it is crucial to pay attention to the general philosophical interpretation of the structure of activity.

The general philosophical concept of activity reveals the specific life of people who purposefully transform nature and social reality, including the political and legal nature and political and legal reality. In our opinion, the most developed rationalistic concept of activity (an integral concept) was offered by the German philosopher G. Hegel. It is not by chance since G. Hegel's concept considers nothing but the dialectics of the structure of activity (Leiashvili, 2013).

According to G. Hegel (1997: 16), activity is "the unity of goals, means and results presented in the process". It is also necessary to take into account our previous studies of activities in the field of organizing and holding elections to government bodies. Based on various aspects of understanding activities, we defined activities in the field of organizing and holding elections to government bodies as a complex phenomenon. Finally, we need to consider the achievements of scientific constitutionalism with due regard to the elemental composition of a related institution, i.e., the election process. As a result, we have concluded that the structure of activities in the field of organizing and holding elections to government bodies should be represented by the following composition of elements: subjects, goals, objectives, principles, functions, means, methods, objects and results.

The elemental composition of the structure of activities in the field of organizing and holding elections to government bodies we developed can be somehow traced in the current election law. Thus, Federal Law No. 67FZ provides Chapter 4 "Election commissions, referendum commissions" concerned with subjects of the activity under study; Article 3 "Principles of conducting elections and referendums in the Russian Federation" defines the basic principles for carrying out such activities, etc.

At the same time, there is no single systemic approach in relation to such activities in election law. The legislator decided to regulate some of its types, i.e., activities in the field of organizing and holding elections of the president (Federal Law Of The Russian Federation, 2003), deputies of the parliament (Federal Law Of The Russian Federation, 2014), etc. 
Natalia Keshikova, Igor Demeshko

694

The concept and structure of activities in the field of organizing and holding elections to government bodies in the theory of constitutional law

\section{Discussion}

Within the framework of constitutional law, scholars studied certain elements of the structure of activities in the field of organizing and holding elections to government bodies only in relation to the following institutions of constitutional law: election law and election process, for example: subjects (Biktagirov, 2010; Lebedeva, 2003; Uraev, 2006; Demyanov, 2018; Krasnov, 2000; Andrianova, 2013); principles (Mateikovich, 1998; Khudolei, 2007; Kuznetsova, 2010; Petrov, 2004; Tarovik, 2009; Kravets, 2016); functions (Agaev, 2010; Vdovin, 2008; Kazachenko, 2005; Volobueva, 2005; Buchin, 2007); means (Zagainov, 2006; Getman, 2010; Samsonov, 2000; Gorbunov, 2000; Shubina, 2006), methods (Zabotin, 2001; Malyukov, 2004; Knyazev, 1999a); objects (S.A. Belov, S.I. Tsybulyak, V.M. Malinovskaya, P.A. Astafichev, O.A. Pleshkova), results (I.A. Borovikova, A.A. Prokhorov, V.N. Rudenko). At the same time, the constituent elements of the structure of activity in the sphere of organizing and holding elections to government bodies in their unity have not been the subject of constitutional and legal research.

Despite a wide range of constitutional and legal studies of election law, election process and procedure for organizing and holding elections, such important elements of the structure of activities in the field of organizing and holding elections to government bodies as goals, tasks and functions carried out to achieve the above-mentioned goals and implement tasks (the main directions of the given activity) have remained understudied.

The significance of such an element as a goal was emphasized by G. Hegel in his dialectics of the structure of activity. It is not an accident that this concept was called purposeful activity since it reveals the deep interdetermination of a goal and its means (Hegel, 1974). G. Hegel's ideas were further developed in modern scientific works concerned with activity types, in which authors consider the corresponding type of activity from the teleological standpoint (Leiashvili, 2013).

Developing the initial doctrine, the authors included functions into the structure of purposeful activity along with the goals. Purposeful activity consists of actions, each of which has its own function. An action is the unity of goals, means and results, in which the result is a function of means. In this case, the result is a realized goal. Since the goal is to obtain resources for other purposes and achieve other results, the means of some actions are the functions that resulted from other actions (Leiashvili, 2013).

In other words, there is not a one-sided relationship between a purpose and a function but rather a mutual relationship. Therefore, all the abovementioned elements (goals, means, functions and results) are mandatory for the structure of activity. Without any of these elements, purposeful activity loses its integrity and ceases to be an optimal system. 


\section{Conclusion}

Goals, objectives and functions were selected as the research subject due to the specifics of the legislator's position that is contained in federal election laws. These federal laws have no indications of the goals and objectives of state policy in the field of organizing and holding elections to government bodies, as well as the goals and objectives of legal regulation in this area. This legislator's position resulted in the deformation of the integral legislative structure. In general, this testifies to the lameness and inefficiency of the legislative structure of Federal Law No. 67-FZ. It "got rid of" such elements as goals and objectives, although their inclusion suggests itself.

Why the legislator neglected these elements of the election law necessary for the implementation of activities in the field of organizing and holding elections to government bodies remains a mystery. Furthermore, the activities conducted in the field of organizing and holding elections to government bodies are purposeful, which is noted by almost all constitutionalists. There is also a positive legislative practice of defining the goals and objectives of state policy and legal regulation of relations emerging in certain activities of society, state, and individuals.

The positive practice can be exemplified by codified federal laws. Thus, the Criminal Code of the Russian Federation contains Article 2 "The Tasks of the Criminal Code of the Russian Federation" that defines the main tasks of criminal regulation. The Housing Code of the Russian Federation includes Article 1 "Main beginnings of the housing legislation" that provides the objectives of housing legislation and Article 2 "Providing conditions for implementation of the right to housing" that highlights the main activities of state authorities and local self-governments to ensure conditions for the exercise of civil rights to housing. Among the current federal laws, we should mention Federal Law of December 29, 2012, No. 273-FZ "On Education in the Russian Federation" which regulates activities in the field of education.

This law contains Article 3 "The basic principles of state policy and legal regulation of the relations in the field of education" and Article 4 "Legal regulation of the relations in the field of education". These two articles clarify the goals and objectives of state policy in the field of education and the legal regulation of relations in this area. Federal Law of December 28, 2010, No. 390-FZ "On Safety" regulates security activities and comprises Article 3 "Content of activities for safety" and Article 4 "State policy in the field of safety". These establish the main goals and objectives, as well as the directions of activities to ensure safety. 


\section{Recommendations}

Guided by the existing positive practice of legal regulation of various social activities, we need to comply with the constitutional and legal regulation of activities in the field of organizing and holding elections to government bodies in federal election laws with the functional-purposeful method. While studying the structure of activities in the field of organizing and holding elections to government bodies, we should consider their goals, objectives and functions through the functional-purposeful method, which involves the study of goals and objectives through the prism of systemic functions in the chosen sphere.

The teleological and functional analysis of such activities reveals the essence of political and legal processes in the field of organizing and holding elections to government bodies and the logical formation of steps, stages and cycles of actions and procedures for carrying out activities in the established area. It also allows creating an optimal conceptual model of both activities in the field of organizing and holding elections to government bodies and an integral, effective legislative structure of its constitutional and legal regulation.

\section{Bibliographic References ${ }^{3}$}

AGAEV, Azer M. 2010. The election process in the Russian Federation: constitutional and legal research: Thesis for a Candidate Degree. Russian Academy of Public Administration under the President of the Russian Federation. Moscow, Russia.

ANDRIANOVA, Maria Alexandrovna. 2013. The constitutional and legal foundations of the participation of mass media in the election process of the Russian Federation]: Thesis for a Candidate Degree. North Caucasus Federal University. Stavropol, Russia.

BIKTAGIROV, Raif Terentyevich. 2010. Election law subjects in the Russian Federation: constitutional and legal research: Extended abstract of thesis for a Doctor Degree. Russian Academy of Public Administration under the President of the Russian Federation. Moscow, Russia.

BIKTAGIROV, Raif Terentyevich. 2012. "The Russian election process as a type of judicial process" In: Izbiratelnoe pravo. Vol. 2, No. 18, pp. 2-13.

3 Some cited sources only have the initial of the name of the author or authors because it was impossible to locate their full name as stable the standard of this journal. 
BIKTAGIROV, Raif Terentyevich. 2020. "The election process as a type of judicial process: theoretical issues of formation" In: Grazhdanin. Vybory. Vlast. Vol. 1, No. 15, pp. 143-158.

BUCHIN, Alexander Alexandrovich. 2007. The constitutional functions of election in modern Russia: Thesis for a Candidate Degree in Law Sciences. Saratov State Academy of Law. Saratov, Russia.

BYCHENKOV, V.M. 2018. Social technologies. Elektronnaya biblioteka IF RAN «Electronic library of the Institute of Philosophy, Russian Academy of Sciences «New philosophical encyclopedia» Available online. In: https://iphlib.ru/library/collection/newphilenc/document/ HASHo147b1e5fd1a015ff851af47. Date of consultation: 08/03/2021.

CHERNYSHOV, V.N; CHERNYSHOV, A.V. 2008. The theory of systems and system analysis: student's textbook. Izd-vo Tamb. gos. tekhn. un-ta. Tambov, Russia.

DANELYAN, Teya Yanovna. 2010. The theory of systems and system analysis: academic and methodological complex. Izd. tsentr EAOI. Moscow, Russia.

DEMESHKO, Igor Vladimirovich. 2015. "The main conceptual approaches to the understanding of election systems" In: Sibirskii yuridicheskii Vestnik. Vol. 2, No. 69, pp. 18-26.

DEMESHKO, Igor Vladimirovich. 2016. "Conceptualizing the notion of «election system» through postnonclassical judicial rationality in the Russian constitutional law" In: Baikal Research Journal. Vol. 7, No. 1, p. 18.

DEMYANOV, Evgeny Viktorovich. 2018. Election commissions in the entities of the Russian Federation: the constitutional and legal aspects of functioning and interaction: Thesis for a Candidate Degree. North Caucasus Federal University. Stavropol, Russia.

FEDERAL LAW OF THE RUSSIAN FEDERATION No. 19-FZ. 2003. "On the election of the President of the Russian Federation. Russia.

FEDERAL LAW OF THE RUSSIAN FEDERATION No. 20-FZ. February 22, 2014. "On the election of deputies of the State Duma of the Federal Assembly of the Russian Federation. Russia.

GERASIMOV, B.I; POPOVA, G.L; ZLOBINA, N.V. 2011. The basic theory of system analysis: quality and choice: student's textbook. Izd-vo FGBOU VPO «TGTU». Tambov, Rissia. 
GETMAN, Lyudmila Sergeevna. 2010. Electoral documents in the Russian election law: Thesis for a Candidate Degree. Far Eastern Federal University. Irkutsk, Russia.

GORBUNOV, Valentin Pavlovich. 2000. The constitutional and legal aspects of improving the election system in the Russian Federation at the current stage of development: Thesis for a Candidate Degree. Russian Academy of Public Administration under the President of the Russian Federation. Moscow, Russia.

HEGEL, Georg Wilhelm Friedrich. 1974. Encyclopedia of the philosophical sciences. Mysl. Moscow, Russia.

HEGEL, Georg Wilhelm Friedrich. 1997. The science of logic. Nauka. Saint Petersburg, Russia.

INFORMATION SYSTEMS AND NETWORKS. n.d. Available online. In: https://tsput.ru/res/informat/sist_seti_fmo/lekcii/lekciy-1.html. Date of consultation: 08/03/2021.

ISKANDAROV, Ural Salavatovich. 2007. "Defining the concept of election process" In: Pravo i gosudarstvo: teoriya i praktika. Vol. 12, No. 36, pp. $13-15$.

IVANCHENKO, Aleksandr Vladimirovich. 1999. Election law and election process in the Russian Federation: textbook for higher education. Izdatelstvo Norma. Moscow, Russia.

KANT, Immanuel. 1994. The principle of judgments on the inner expediency of organisms. In: GALYGA, A.V. (Ed.). Collected edition in eight vols.: anniversary edition 1794-1994. Moscow, Russia.

KAZACHENKO, Anna Aleksandrovna. 2005. The constitutional and legal regulation of the organization and activity of political parties in modern democratic states: Thesis for a Candidate Degree. Moscow University of the Ministry of Internal Affairs of the Russian Federation. Moscow, Russia.

KESHIKOVA, Natalia Vladimirovna. 2001. Procedures for the organization and holding of elections to the Russian government bodies: Extended abstract of thesis for a Candidate Degree. St. Petersburg University of the Ministry of Internal Affairs of the Russian Federation. Saint Petersburg, Russia.

KESHIKOVA, Natalia Vladimirovna; DEMESHKO, Igor Vladimirovich. 2015. The understanding of election system through postnonclassical juidicial rationality in the Russian constitutional law. In: KESHIKOVA, 
N.V. (Ed.). Problemy organizatsii organov gosudarstvennoi vlasti i mestnogo samoupravleniya: istoriya, teoriya, praktika i perspektivy. The proceedings of the scientific conference, Irkutsk, Russia, April 4-5, Irkutsk: Baikal State University of Economics and Law.

KHUDOLEI, Dmitry Mikhailovich. 2007. The principle of equal voting rights in the Russian Federation: Thesis for a Candidate Degree. Perm State University. Perm, Russia.

KHUDOLEI, Dmitry Mikhailovich. 2015. “The concept of election process" In: Vestnik Permskogo universiteta. Yuridicheskie nauki. Vol. 2, No. 28, pp. 18-28.

KNYAZEV, Sergey Dmitrievich. 1999a. Election law in the legal system of the Russian Federation: theoretical and practical issues: Thesis for a Doctor Degree. Far Eastern State University. Vladivostok, Russia.

KNYAZEV, Sergey Dmitrievich. 1999b. “The election process: concept, specifics and structure" In: Izvestiya vysshikh uchebnykh zavedenii. Pravovedenie. Vol. 3, No. 226, pp. 42-54.

KRASNOV, Konstantin Vladimirovich. 2000. Election process subjects in the Russian Federation: Thesis for a Candidate Degree. Moscow State University named after M.V. Lomonosov. Moscow, Russia.

KRAVETS, Daria Alekseevna. 2016. The constitutional principle of ballot voting: content and realization in the Russian Federation: Thesis for a Candidate Degree. Penza State University. Penza, Russia.

KUZNETSOVA, Olga Viacheslavovna. 2010. Realizing the constitutional principle of equal voting rights of the Russian citizens in passive electioneering: Thesis for a Candidate Degree. Saratov State University named after N.G. Chernyshevsky. Saratov, Russia.

LEBEDEVA, Yulia Nikolaevna. 2003. Citizens as subjects of the Russian election law: Thesis for a Candidate Degree. Khabarovsk State Academy of Economics and Law. Khabarovsk, Russia.

LEIASHVILI, Paata R. 2013. Economic activity: teleological analysis. DirektMedia. Moscow, Russia.

MALYUKOV, Andrey Alexandrovich. 2004. Legal regulation in election campaigning in the Russian Federation: Thesis for a Candidate Degree. Moscow University for the Humanities. Moscow, Russia.

MASLOVSKAYA, Maria Vladilenovna. 1999. The election process in the Russian Federation: Thesis for a Candidate Degree. Volgograd Academy of Public Administration. Volgograd, Russia. 
Natalia Keshikova, Igor Demeshko

700

The concept and structure of activities in the field of organizing and holding elections to government bodies in the theory of constitutional law

MATEIKOVICH, Maxim Stanislavovich. 1998. The legal regulation of elections to government bodies of the constituent entities of the Russian Federation: Thesis for a Candidate Degree, Tyumen State University. Tyumen, Russia.

MAZITOV, Ramil Giniyatovich. 2009. "The election process as a political subprocess" In: Vestnik Bashkirskogo universiteta. Vol. 14, No. 2, pp. 620-622,

MELEKHIN, Aleksandr V. 2009. The theory of state and law: Student's textbook. Market DS korporeyshn. Moscow, Russia.

OBSHCHII TOLKOVYI SLOVAR RUSSKOGO YAZYKA (The general explanatory dictionary of the Russian language). n.d. Available online. In: http://tolkslovar.ru/s13370.html. Date of consultation: 08/03/2021.

PETROV, Igor Vladislavovich. 2004. Implementing the principle of equal voting rights in the Russian Federation. Thesis for a Candidate Degree. Saratov State Academy of Law. Saratov, Russia.

POLESHCHUK, Igor Alexandrovich. 2015. "The structural aspect of organizing systems" In: Nauka i obrazovanie segodnya. Vol. 1, pp. 53-56.

SADOVSKII, V. N; BABAITSEV, A.Yu; DROZDOV, N.D; CHERNYSHOV, V.N; CHERNYSHOV, A.V; ALEXANDROV, A.V. 2021. Sistema [System]. Gumanitarnyi portal: Kontsepty [The humanities portal: Concepts]. Available online. In: https://gtmarket.ru/concepts/7091. Date of consultation: 08/03/2021.

SAMSONOV, Vladimir Alexandrovich. 2000. The constitutional means of protecting the election rights of citizens: Thesis for a Candidate Degree. Volgograd Academy of Public Administration. Volgograd, Russia.

SHUBINA, Elena Valentinovna. 2006. Forming thelaw-making(representative) bodies of state power in the entities of the Russian Federation: legal and organizational issues: Thesis for a Candidate Degree. Chelyabinsk State University. Chelyabinsk, Russia.

SUPREME COURT OF THE RUSSIAN FEDERATION. 2019. September 2. Appellation decision of the Judicial Council of Administrative Affairs of the Supreme Court of the Russian Federation No. 92-APA19-10. Available online. In: https://legalacts.ru/sud/apelliatsionnoe-opredeleniesudebnoi-kollegii-po-administrativnym-delam-verkhovnogo-suda-rfot-02092019-n-92-apa19-10/. Date of consultation: 08/03/2021.

SUPREME COURT OF THE RUSSIAN FEDERATION. 2019. September 7. Appellation decision of the Judicial Council of Administrative Affairs of 
the Supreme Court of the Russian Federation No.78-APA19-68. Available online. In: https://legalacts.ru/sud/apelliatsionnoe-opredeleniesudebnoi-kollegii-po-administrativnym-delam-verkhovnogo-sudarossiiskoi-federatsii-ot-07092019-n-78-apa19-68/. Date of consultation: 08/03/2021.

SUPREME COURT OF THE RUSSIAN FEDERATION. 2019. September 16. Appellation decision of the Judicial Council of Administrative Affairs of the Supreme Court of the Russian Federation No. 11-APA19-27. Available online. In: https://legalacts.ru/sud/apelliatsionnoe-opredeleniesudebnoi-kollegii-po-administrativnym-delam-verkhovnogo-suda-rfot-16092019-n-127-apa19-27/. Date of consultation: 08/03/2021.

TAROVIK, Svetlana Sergeevna. 2009. Implementing the principles of universality, freedom and equality in the election law of the Russian Federation: Thesis for a Candidate Degree. Saint Petersburg State University of Economics and Finance. Saint Petersburg, Russia.

URAEV, Nikolay Nikolaevich. 2006. The constitutional and legal status of observers in the Russian election law: Thesis for a Candidate Degree. Kazan State University named after V.I. Ulyanov-Lenin. Kazan, Russia.

VDOVIN, Dmitry Nikolaevich. 2008. Judicial functions in the election process of the Russian Federation: Thesis for a Candidate Degree. Russian Academy of Justice. Moscow, Russia.

VOLKOVA, Violetta Nikolaevna; DENISOV, Anatoly Alekseevich. 2014. The theory of systems and system analysis: textbook for academic bachelors. Izd-vo Yurait. Moscow, Russia.

VOLOBUEVA, Alla Nikolaevna. 2005. The constitutional and legal foundations of the organization and activity of political parties in the Russian Federation: Thesis for a Candidate Degree. Saratov Law Institute of the Ministry of Internal Affairs of the Russian Federation. Saratov, Russia.

VEDENEEV, Yu. A. 2003. Introduction to election law. Student's textbook. RTsOIT. Moscow, Russia.

YAMASHKIN, Yu.V; NOVOKRESHCHENOVA, O.A. 2016. The systemic approach to organization: academic and methodological complex. Mordov. gos. un-t. Saransk, Russia.

ZABOTIN, Vyacheslav Petrovich. 2001. Election rights of the Russian citizens and the role of internal affairs bodies in their realization: Thesis for a Candidate Degree. Academy of Management of the Ministry of Internal Affairs of the Russian Federation. Moscow, Russia. 
ZAGAINOV, Sergey Vladimirovich. 2006. The election process in modern Russia: constitutional and legal aspects: Thesis for a Candidate Degree in Law Sciences. Adyghe branch of the Moscow Open Social University. Maikop, Russia.

ZINOVEV, Aleksandr Vladimirovich; POLYASHOVA, Inna Sergeevna. 2003. The election system of Russia: theory, practice and perspective. Yuridicheskii tsentr Press. Saint Petersburg, Russia. 

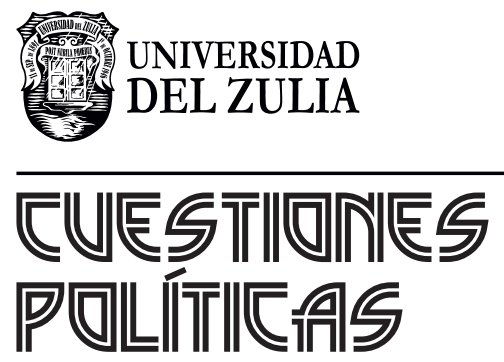

Vol. 39 N $^{\circ} 71$

Esta revista fue editada en formato digital y publicada en diciembre de 2021, por el Fondo Editorial Serbiluz, Universidad del Zulia. Maracaibo-Venezuela 